\title{
Mechanistic basis for protection of differentiated SH-SY5Y cells by oryzanol-rich fraction against hydrogen peroxide-induced neurotoxicity
}

Norsharina Ismail ${ }^{1}$, Maznah Ismail ${ }^{1,2^{*}}$, Mustapha Umar Imam¹', Nur Hanisah Azmi ${ }^{1}$, Siti Farhana Fathy', Jhi Biau Foo ${ }^{1}$ and Muhammad Firdaus Abu Bakar ${ }^{1}$

\begin{abstract}
Background: Apoptosis is often the end result of oxidative damage to neurons. Due to shared pathways between oxidative stress, apoptosis and antioxidant defence systems, an oxidative insult could end up causing cellular apoptosis or survival depending on the severity of the insult and cellular responses. Plant bioresources have received close attention in recent years for their potential role in regulating the pathways involved in apoptosis and oxidative stress in favour of cell survival. Rice bran is a bioactive-rich by-product of rice milling process. It possesses antioxidant properties, making it a promising source of antioxidants that could potentially prevent oxidative stress-induced neurodegenerative diseases.
\end{abstract}

Methods: Thus, the present study investigated the neuroprotective properties of oryzanol-rich fraction (ORF) against hydrogen peroxide $\left(\mathrm{H}_{2} \mathrm{O}_{2}\right)$-induced neurotoxicity in differentiated human neuroblastoma SH-SY5Y cells. ORF was extracted from rice bran using a green technology platform, supercritical fluid extraction system. Furthermore, its effects on cell viability, morphological changes, cell cycle, and apoptosis were evaluated. The underlying transcriptomic changes involved in regulation of oxidative stress, apoptosis and antioxidant defence systems were equally studied.

Results: ORF protected differentiated SH-SY5Y cells against $\mathrm{H}_{2} \mathrm{O}_{2}$-induced neurotoxicity through preserving the mitochondrial metabolic enzyme activities, thus reducing apoptosis. The mechanistic basis for the neuroprotective effects of ORF included upregulation of antioxidant genes (catalase, SOD 1 and SOD 2), downregulation of pro-apoptotic genes (JNK, TNF, ING3, BAK1, BAX, p21 and caspase-9), and upregulation of anti-apoptotic genes (ERK1/2, AKT1 and NF-Kß).

Conclusion: These findings suggest ORF may be an effective antioxidant that could prevent oxidative stress-induced neurodegenerative disorders.

Keywords: Neuroprotective, Rice bran, Oryzanol-rich fraction, Hydrogen peroxide, Supercritical fluid extraction system, Multiplex GeXP, SH-SY5Y cells

\footnotetext{
* Correspondence: maznahis@upm.edu.my

${ }^{1}$ Nutricosmeceuticals and Nutrigenomics Programme, Laboratory of

Molecular Biomedicine, Institute of Bioscience, Universiti Putra Malaysia, Serdang, Selangor 43400, Malaysia

${ }^{2}$ Department of Nutrition and Dietetics, Faculty of Medicine and Health

Sciences, Universiti Putra Malaysia, Serdang, Selangor 43400, Malaysia
} 


\section{Background}

Antioxidant defense systems scavenge reactive oxygen species (ROS) in biological systems as a way to prevent build-up of their levels beyond physiologically acceptable limits. At a certain threshold, however, cells become unable to remove excess ROS, leading to oxidative stress, which is linked to the degenerative processes of aging as well as pathogenesis of many diseases [1]. Cellular response to oxidative stress is dependent on the type of cell. Responses to neuronal oxidative stress are particularly interesting because of their contrasting nature in comparison to other cells. Furthermore, with increasing longevity due to better health care systems, and the delicate nature of the nervous system, considerable interest has grown in factors linked to neurodegenerative diseases in a bid to improve quality of life of the elderly.

Superoxide anions, hydrogen peroxide $\left(\mathrm{H}_{2} \mathrm{O}_{2}\right)$ and the hydroxyl radical have been indicated as potent mediators of neuronal oxidative stress [2]. They elicit a complex cascade of events that may eventually remove the initiating stimulus or result in apoptotic death of the cells, depending on the severity of the damage [1]. Mitochondria have been suggested as early targets of oxidative damage, in which cause damage leads to cytochrome c release through a process closely regulated by the Bcl-2 family proteins (Bcl-2, Bax and Bid). Cytochrome $\mathrm{c}$ in conjunction with Apaf-1 then activates the caspases, which cleave DNA repair enzymes including PARP, eventually leading to cellular damage and apoptosis [3]. Interestingly, cell survival signaling pathways are closely linked to those that end up in apoptosis. Notably, the major signaling pathways in response to oxidative stress insults include mitogen-activated protein kinases (MAPKs), Akt pathway and nuclear factor- $k \beta(N F-k \beta)$ signaling. MAPKs encompass a large number of serine/threonine kinases involved in regulating cellular processes including proliferation, differentiation, stress adaptation, and apoptosis. These include the extracellular signal-regulated kinases (ERK), the c-Jun N-terminal kinases (JNK), and the p38 kinases. The ERK pathway is linked to the regulation of cell proliferation, while the JNK and p38 pathways are more strongly tied to stress [1].

Furthermore, Akt activation mediated through phosphatidylinositol-3 kinase (PI3K) pathway has been reported to inhibit apoptosis by inhibiting caspase- 9 and Bad. ERK1/2 activation through active Ras and PKA has also been shown to block cytochrome c release through Bad-mediated Bcl-xL inhibition [3]. On the other hand, $\mathrm{NF}-\mathrm{\kappa B}$ also regulates inflammation, immune responses, control of cell division and apoptosis, and its manipulation is reported to be valuable in treating ischemic stroke, physical trauma to the brain or spinal cord, and neurodegenerative disorders including Alzheimer's disease and
Parkinson's disease [4]. Overall, the modulation of these complex pathways constitutes an important avenue for therapeutic interventions aimed at limiting oxidative damage or attenuating its consequent effects [1].

In recent years, growing concerns of side effects associated with pharmacological agents have generated interest in the therapeutic potentials of plant bioresources. Rice bran is a by-product of the rice milling process, and was previously considered a waste. Now, it is known to contain fat, proteins and bioactives including $\gamma$-oryzanol (a mixture of ferulic acid esters of triterpene alcohols and sterols), tocols (tocopherols and tocotrienols) and unsaturated fatty acids [5-9], phytosterols, stanols and policosanols [10]. Its functional effects include antioxidant, anti-inflammatory, cholesterol-lowering and anti-diabetic, anti-cancer, anti-hypertensive and glucose metabolism [5,11-15]. Simultaneous extraction and use of multiple bioactive compounds from plants have been reported to potentiate the effects of any one of the bioactives through synergy. Hence, our choice of oryzanol-rich fraction (ORF) in the current study was to maximize the benefits from the rice bran bioactives, while using a green technology, supercritical fluid extraction (SFE) system [16-23].

In the present study, extracted ORF was studied for its ability to regulate processes leading up to oxidative stress and apoptosis in differentiated SH-SY5Y cells.

\section{Methods \\ Reagents}

Rice bran samples were obtained from local milling company, Padiberas National Berhad (BERNAS) at Kuala Selangor, Malaysia. The human neuroblastoma SH-SY5Y cell line was obtained from American Type Culture Collection (Manassas, VA, USA). Minimum essential Eagle's medium, Ham's nutrient mixture F-12, fetal bovine serum and gentamicin were obtained from Sigma (St. Louis, MO, USA). Total RNA Isolation kit was obtained from RBC Bioscience Corp. (Taipei, Taiwan), GenomeLab $^{\text {TM }}$ GeXP Start Kit was purchased from Beckman Coulter Inc. (Miami, FL, USA), Magnesium chloride and DNA Taq polymerase were from Thermo Fisher Scientific (Pittsburgh, PA, USA).

\section{Extraction of ORF by SFE system}

ORF was prepared using SFE system (Thar $1000 \mathrm{~F}$, Thar Technologies, Inc., Pittsburgh, PA, USA). Briefly, $100 \mathrm{~g}$ of stabilized rice bran was placed into the SFE extraction vessel and extraction parameters were set at 600 bars pressure, temperature of $40^{\circ} \mathrm{C}$ and carbon dioxide flow rate of $30 \mathrm{~g} / \mathrm{min}$. ORF was collected from collection vessel when the ranges of pressure and temperature reached $100-300$ bar and $40^{\circ} \mathrm{C}-60^{\circ} \mathrm{C}$, respectively. 


\section{Cell culture}

The human neuroblastoma SH-SY5Y cells were maintained in complete culture medium containing 1:1 mixture of Minimum essential Eagle's medium and Ham's nutrient mixture F-12, supplemented with $10 \%$ fetal bovine serum, 1\% MEM non-essential amino acids and $50 \mu \mathrm{g} / \mathrm{mL}$ gentamicin. Cells were maintained at $37^{\circ} \mathrm{C}$ under $5 \% \mathrm{CO}_{2} / 95 \%$ air.

\section{MTT assay}

SH-SY5Y cells were seeded into 96-well culture plates at a density of $2 \times 10^{5}$ cells $/ \mathrm{mL}$ and allowed to attach. Then, $24 \mathrm{~h}$ after seeding, the cells were differentiated with retinoic acid $(10 \mu \mathrm{M})$ for 6 days prior to treatment. The differentiated cells were then pretreated for $24 \mathrm{~h}$ with ORF prepared in serum-free medium at concentrations of 1,10 and $100 \mu \mathrm{g} / \mathrm{mL}$. The treated cells were then challenged with $250 \mu \mathrm{M} \mathrm{H}_{2} \mathrm{O}_{2}$ for $24 \mathrm{~h}$, as reported in our previous publication [24]. MTT [3-(4,5-dimethylthiazol2-yl)-2,5-diphenyl-tetrazolium bromide, Sigma, St. Louis, $\mathrm{MO}, \mathrm{USA}$ ] was added to the wells and allowed to incubate in the dark at $37^{\circ} \mathrm{C}$ for $4 \mathrm{~h}$. The amount of MTT formazan product was determined by measuring absorbance using a Microplate reader (Opsys MR, Thermo Labsystems, Franklin, MA) at $570 \mathrm{~nm}$.

\section{Acridine orange (AO)-propidium iodide ( $\mathrm{PI}$ ) double staining cell morphological assessment}

Approximately $2 \times 10^{5}$ cells $/ \mathrm{mL}$ of SH-SY5Y were seeded into 6-well plate and allowed to attach. Then, $24 \mathrm{~h}$ after seeding, the cells were differentiated with retinoic acid $(10 \mu \mathrm{M})$ for 6 days prior to treatment. The differentiated cells were then pretreated for $24 \mathrm{~h}$ with $100 \mu \mathrm{g} / \mathrm{mL}$ ORF prepared in serum-free medium, and subsequently exposed to $250 \mu \mathrm{M} \mathrm{H}_{2} \mathrm{O}_{2}$ for $24 \mathrm{~h}$. The cells were then trypsinized and $10 \mu \mathrm{L}$ of the cell suspension was mixed with $10 \mu \mathrm{L}$ of $\mathrm{AO}(50 \mu \mathrm{g} / \mathrm{mL})$ and $\mathrm{PI}(50 \mu \mathrm{g} / \mathrm{mL})$ and placed on a glass slide. The cells were viewed under a fluorescence microscope (Leica, Germany).

\section{Cell cycle analysis}

SH-SY5Y cells were seeded into 6-well plates at a density of $2 \times 10^{5}$ cells $/ \mathrm{mL}$. The cells were differentiated with $10 \mu \mathrm{M}$ retinoic acid for 6 days prior to treatment. The cells were pretreated with $100 \mu \mathrm{g} / \mathrm{mL}$ ORF for $24 \mathrm{~h}$ with subsequent exposure to $250 \mu \mathrm{M} \mathrm{H}_{2} \mathrm{O}_{2}$ for $24 \mathrm{~h}$. The cells were harvested using $0.1 \%$ trypsin-EDTA, fixed in $70 \%$ ethanol and kept at $-20^{\circ} \mathrm{C}$ overnight. After fixation, the pellets were washed with PBS to remove ethanol and further resuspended in $25 \mu \mathrm{L}$ of RNAse, $50 \mu \mathrm{L}$ of propidium iodide and $425 \mu \mathrm{L}$ of PBS to make up the volume to $500 \mu \mathrm{L}$. After $30 \mathrm{~min}$ of incubation in the dark at $4^{\circ} \mathrm{C}$, the DNA contents of the cells were analyzed using flow cytometer with Summit v4.3 software (Cyan ADP, Beckman Coulter, Brea, CA, USA).

\section{Annexin V-FITC and propidium iodide staining assay}

SH-SY5Y cells were seeded in 6-well plates at a density of $2 \times 10^{5}$ cells $/ \mathrm{mL}$. The cells were differentiated with $10 \mu \mathrm{M}$ retinoic acid for 6 days prior to treatment. The cells were pretreated with $100 \mu \mathrm{g} / \mathrm{mL}$ ORF for $24 \mathrm{~h}$ followed by exposure to $250 \mu \mathrm{M} \mathrm{H}_{2} \mathrm{O}_{2}$ for another $24 \mathrm{~h}$. The subsequent procedures were carried out according to the instructions provided by the manufacturer of APOPTEST-FITC kit (Beckman Coulter, Brea, CA, USA). Briefly, cells were harvested using $0.1 \%$ trypsin-EDTA and cell pellets were resuspended in ice-cold $1 \mathrm{X}$ binding buffer. One microliter of Annexin V-FITC solution and $5 \mu \mathrm{L}$ of propidium iodide were added to $100 \mu \mathrm{L}$ of the cell suspension. The tube was incubated on ice for $15 \mathrm{~min}$ in the dark followed by addition of $400 \mu \mathrm{L}$ ice-cold $1 \mathrm{X}$ binding buffer and mixing gently. The samples were analyzed using flow cytometer with Summit software v4.3 (CyAN ADP, Beckman Coulter, Brea, CA, USA).

\section{GeXP multiplex gene expression analysis RNA extraction}

SH-SY5Y cells were seeded into 6-well plates at a density of $2 \times 10^{5}$ cells $/ \mathrm{mL}$. The cells were differentiated with $10 \mu \mathrm{M}$ retinoic acid for 6 days prior to treatment. The cells were pretreated with $100 \mu \mathrm{g} / \mathrm{mL}$ ORF for $24 \mathrm{~h}$ with subsequent exposure to $250 \mu \mathrm{M} \mathrm{H}_{2} \mathrm{O}_{2}$ for $24 \mathrm{~h}$. Total RNA was extracted using Total RNA Isolation kit (RBC Bioscience Corp., Taiwan) according to the manufacturer's protocol. RNA concentration was quantified using NanoDrop spectrophotometer (Thermo Scientific Nanodrop, NanoDrop Technologies, Wilmington, DE, USA), and ratios of A260/230 and A260/280 between 1.8 and 2.0 were used to indicate RNA of high purity.

\section{Primer design}

Nucleotide sequences of the genes of interest and housekeeping genes (Table 1) were obtained from National Center for Biotechnology Information GenBank Database, while the internal control (KanR) was supplied by Beckman Coulter Inc. (Miami, FL, USA). The specificity validation of the nucleotide sequences was performed using NCBI-nucleotide-BLAST. Additional 37 base pair of universal tag sequences were attached to each forward and reverse primers. Synthesis of primers was done by First Base Ltd. (Selangor, Malaysia) and diluted according to instructions from Beckman Coulter Inc (Miami, FL, USA).

\section{cDNA synthesis}

The complementary DNA (cDNA) was synthesized using $50 \mathrm{ng} / \mu \mathrm{L}$ RNA of each sample. The reverse transcription 
Table 1 Gene name, accession number, reverse and forward primer sequences used in GeXP multiplex gene expression analysis

\begin{tabular}{|c|c|c|c|}
\hline \multirow[t]{2}{*}{ Gene name } & \multirow[t]{2}{*}{ Accession number } & \multicolumn{2}{|l|}{ Primer sequences* with universal tags } \\
\hline & & Forward & Reverse \\
\hline \multicolumn{4}{|l|}{ Antioxidant genes } \\
\hline Catalase & NM_001752 & AGGTGACACTATAGAATAGAAGTGCGGAGATTCAACACT & GTACGACTCACTATAGGGAACACGGATGAACGCTAAGCT \\
\hline SOD 1 & NM_000454 & AGGTGACACTATAGAATATCATCAATTTCGAGCAGAAGG & GTACGACTCACTATAGGGATGCTITITCATGGACCACC \\
\hline SOD 2 & NM_000636 & AGGTGACACTATAGAATACATCAAACGTGACTTTGGTTC & GTACGACTCACTATAGGGACTCAGCATAACGATCGTGGTT \\
\hline \multicolumn{4}{|c|}{ Downstream apoptotic genes } \\
\hline BAD & NM_004322 & AGGTGACACTATAGAATACGGAGGATGAGTGACGAGTT & GTACGACTCACTATAGGGAGGAGTTTCGGGATGTGGAG \\
\hline TNF & NM_000594 & AGGTGACACTATAGAATACTATCTGGGAGGGGTCTTCC & GTACGACTCACTATAGGGAATGTTCGTCCTCCTCACAGG \\
\hline ING3 & NM_198267 & AGGTGACACTATAGAATAAGGTTCAGTTGGCAAACCAG & GTACGACTCACTATAGGGAAGCCAAAAGTGAGCATGTGTT \\
\hline BAK1 & BC004431 & AGGTGACACTATAGAATAAGCCTGTTTGAGAGTGGCAT & GTACGACTCACTATAGGGAAGTGATGCAGCATGAAGTCG \\
\hline BAX & BC014175 & AGGTGACACTATAGAATACCCTTTTGCTTCAGGGTTC & GTACGACTCACTATAGGGACAAAGTAGAAAAGGGCGACAA \\
\hline p21 & NM_000389 & AGGTGACACTATAGAATATTAGCAGCGGAACAAGGAGT & GTACGACTCACTATAGGGAAGCCGAGAGAAAACAGTCCA \\
\hline CAS-9 & NM_001229 & AGGTGACACTATAGAATAGGGCTCACTCTGAAGACCTG & GTACGACTCACTATAGGGATCTGGAAGCTGCTAAGAGCC \\
\hline BCL-2 & M14745 & AGGTGACACTATAGAATAACCACTAATTGCCAAGCACC & GTACGACTCACTATAGGGATTTCCATCCGTCTGCTCTT \\
\hline \multicolumn{4}{|c|}{ Upstream apoptotic genes } \\
\hline ERK1/2 & NM_002745 & AGGTGACACTATAGAATAGGAGCAGTATTACGACCCGA & GTACGACTCACTATAGGGAGATGTCTGAGCACGTCCAGT \\
\hline p53 & NM_001126117 & AGGTGACACTATAGAATAGGGGAGCAGGGCTCA & GTACGACTCACTATAGGGAAAAATGGCAGGGGAGGG \\
\hline JNK & NM_139046 & AGGTGACACTATAGAATACAGAAGCTCCACCACCAAAGAT & GTACGACTCACTATAGGGAGCCATTGATCACTGCTGCAC \\
\hline PARP1 & NM_001618 & AGGTGACACTATAGAATATATCGAGTCGAGTACGCCAA & GTACGACTCACTATAGGGAGTGTGGGACTITTCCATCAAA \\
\hline AKT1 & NM_001014431 & AGGTGACACTATAGAATAGAGGAGATGGACTTCCGGTC & GTACGACTCACTATAGGGAAGGATCTTCATGGCGTAGTAGC \\
\hline NF-kB & NM_001077493 & AGGTGACACTATAGAATAGCGGGCGTCTAAAATTCTG & GTACGACTCACTATAGGGATTCCACGATCACCAGGTAGG \\
\hline p38 & NM_001315 & AGGTGACACTATAGAATATTCAGTCTTTGACTCAGATGCC & GTACGACTCACTATAGGGAGTCAGGCTITTCCACTCATCT \\
\hline \multicolumn{4}{|c|}{ Housekeeping genes } \\
\hline GAPDH $^{\mathrm{a}}$ & NM_002046 & AGGTGACACTATAGAATAAAGGTGAAGGTCGGAGTCAA & GTACGACTCACTATAGGGAGATCTCGCTCCTGGAAGATG \\
\hline Hyaluronidase $^{a}$ & AJ000099 & AGGTGACACTATAGAATACAGCAGTTCATGCTGGAGAC & GTACGACTCACTATAGGGACCAGGTAGACAGACGGGAAG \\
\hline 18 sRNA $^{\mathrm{a}}$ & M10098 & AGGTGACACTATAGAATAGGAGTGGAGCCTGCGGCTTAA & GTACGACTCACTATAGGGATAGCATGCCAGAGTCTCGTT \\
\hline Actb $^{a, \#}$ & NM_001101 & AGGTGACACTATAGAATAGATCATTGCTCCTCCTGAGC & GTACGACTCACTATAGGGAAAAGCCATGCCAATCTCATC \\
\hline $\operatorname{Kan}(r)^{b}$ & - & AGGTGACACTATAGAATAATCATCAGCATTGCATTCGATTCCTGTTTG & GTACGACTCACTATAGGGAATTCCGACTCGTCCAACATC \\
\hline
\end{tabular}

*Based on the Homo sapien gene sequences adopted from the National Center for Biotechnology Information GenBank Database.

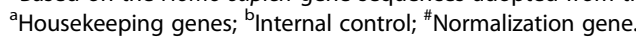


(RT) reaction was performed according to GenomeLab ${ }^{\text {тм }}$ GeXP Start Kit instructions (Beckman Coulter Inc., Miami, FL, USA): $1 \mu \mathrm{L}$ of RNA sample, $4 \mu \mathrm{L}$ of $5 \mathrm{X}$ RT buffer, $2 \mu \mathrm{L}$ of RT multiplex reverse primers, $1 \mu \mathrm{L}$ of KanR, $1 \mu \mathrm{L}$ of reverse transcriptase and $11 \mu \mathrm{L}$ of DNAse/ RNase free water. $\mathrm{CDNA}$ was synthesized according to the reaction protocol: $48^{\circ} \mathrm{C}$ for $1 \mathrm{~min}, 42^{\circ} \mathrm{C}$ for $60 \mathrm{~min}, 95^{\circ} \mathrm{C}$ for $5 \mathrm{~min}$ and $4^{\circ} \mathrm{C}$ hold in XP Thermal Cycler (BIOER Technology, Hangzhou, China).

\section{PCR amplification}

PCR reactions were carried out using GeXP Start Kit (Beckman Coulter, Miami, FL, USA) consisting of cDNA sample taken from the RT reaction $(9.3 \mu \mathrm{L}$ each), 5X PCR buffer, $25 \mathrm{mM}$ magnesium chloride, PCR multiplex forward primer and Thermo-Start DNA polymerase. Amplification was done in an XP Thermal Cycler (BIOER Technology, Hangzhou, China) using $95^{\circ} \mathrm{C}$ for $10 \mathrm{~min}$, followed by 34 cycles of $94^{\circ} \mathrm{C}$ for $30 \mathrm{sec}, 55^{\circ} \mathrm{C}$ for $30 \mathrm{sec}, 70^{\circ} \mathrm{C}$ for $1 \mathrm{~min}$ and $4^{\circ} \mathrm{C}$ hold.

\section{GeXP multiplex data analysis}

The PCR product ( $1 \mu \mathrm{L}$ each) was mixed with $38.5 \mu \mathrm{L}$ of sample loading solution and $0.5 \mu \mathrm{L}$ of DNA Size Standard-400 (Beckman Coulter Inc., Miami, FL, USA). The PCR products were then separated in the GenomeLab GeXP Genetic Analysis System (Beckman Coulter, Brea, CA, USA) by capillary gel electrophoresis according to their nucleotide sizes. The dye signal strength was measured in arbitrary units (A.U.) of optical fluorescence. The data were analyzed using the Fragment Analysis module of the GeXP system software and then transferred to the analysis module of eXpress Profiler software. Normalization was performed with $\beta$-actin as reference gene, according to manufacturer's instructions.

\section{Statistical analysis}

Statistical analysis $(\mathrm{n}=3)$ was conducted by one-way analysis of variance with Tukey's multiple comparison test using Statistical Package for the Social Sciences (SPSS Inc., Chicago, Illinois, USA) version 21.0 and $p<0.05$ was considered as significantly different.

\section{Results}

\section{ORF-protected SH-SY5Y cells against $\mathrm{H}_{2} \mathrm{O}_{2}$-induced neurotoxicity}

Treatment of SH-SY5Y cells with ORF $(1-100 \mu \mathrm{g} / \mathrm{mL})$ did not show much toxicity (Figure 1A). However, treatment of the cells with $250 \mu \mathrm{M} \mathrm{H} \mathrm{H}_{2}$ for $24 \mathrm{~h}$ resulted in significant cell death [24]. When cells were pretreated with ORF for $24 \mathrm{~h}$ and subsequently exposed to $250 \mu \mathrm{M} \mathrm{H} \mathrm{H}_{2} \mathrm{O}_{2}$ for another $24 \mathrm{~h}$, the resulting toxicities observed were not as significant as with $\mathrm{H}_{2} \mathrm{O}_{2}$ treatment alone (Figure $1 \mathrm{~B}$ ).

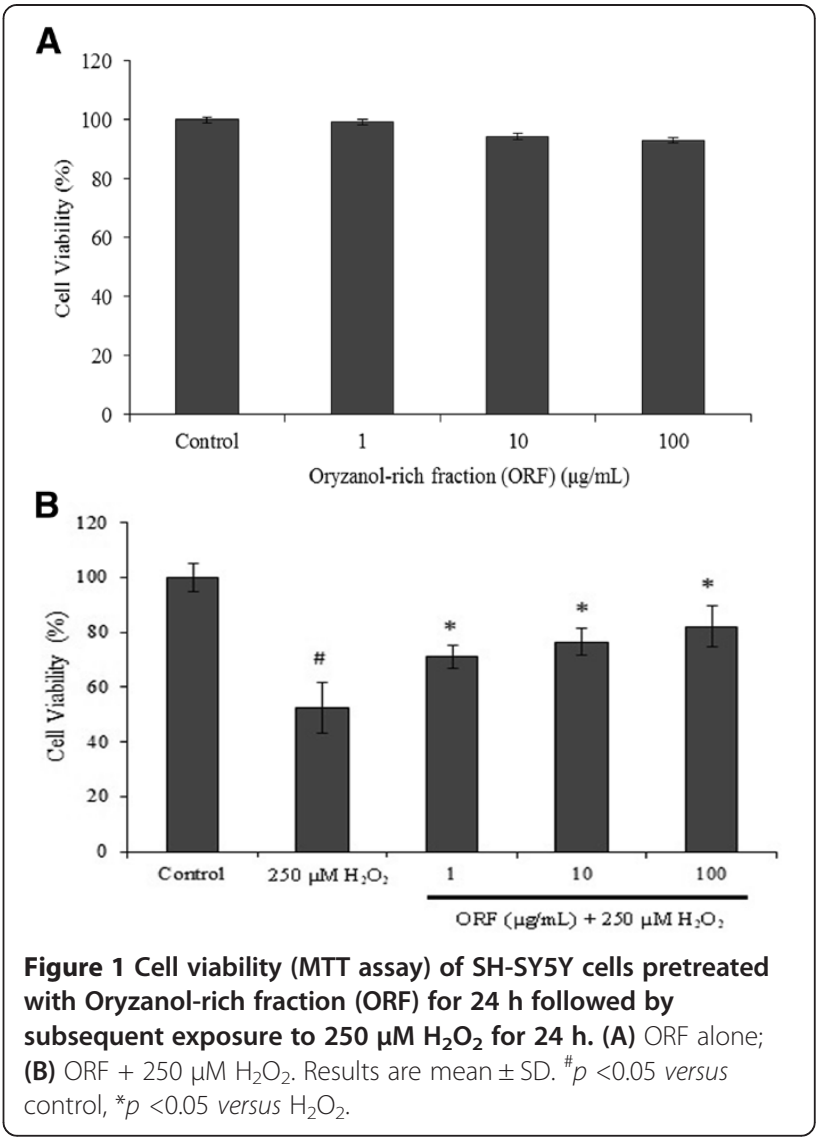

\section{ORF prevented $\mathrm{H}_{2} \mathrm{O}_{2}$-induced morphological changes in SH-SY5Y cells}

$\mathrm{AO} / \mathrm{PI}$ double staining distinguishes between viable, apoptotic and necrotic cells. Viable cells will normally show round and green nuclei, similar to those of the untreated cells in this study (Figure 2A). Late apoptotic and necrotic cells will stain orange and red as displayed by the $\mathrm{H}_{2} \mathrm{O}_{2}-$ treated cells (Figure 2B). In this study, the nuclei of the cells pretreated with ORF stained orange and red but with less intensity that those of $\mathrm{H}_{2} \mathrm{O}_{2}$-treated cells (Figure 2C).

\section{ORF protected SH-SY5Y cells against $\mathrm{H}_{2} \mathrm{O}_{2}$-induced cell death}

Figure 3 showed significant cell death (at Sub G1) (40\% \pm $5.88 \%$ ) upon exposure to $250 \mu \mathrm{M} \mathrm{H}_{2} \mathrm{O}_{2}$ in comparison to untreated cells $(8 \% \pm 2.34 \%), p<0.05$. In contrast, pretreatment with $100 \mu \mathrm{g} / \mathrm{mL}$ ORF did not produce as much dead cells $(14 \% \pm 5.0 \%)$ as with $\mathrm{H}_{2} \mathrm{O}_{2}$ treatment alone, $p<0.05$. In addition, there was no significant difference in cell populations at $\mathrm{S}$ and $\mathrm{G} 2 / \mathrm{M}$ phases among control, $\mathrm{H}_{2} \mathrm{O}_{2}$ alone and ORF treatment.

Figure 4 showed that exposure of SH-SY5Y cells to $\mathrm{H}_{2} \mathrm{O}_{2}$ demonstrated significant differences in viable, late 

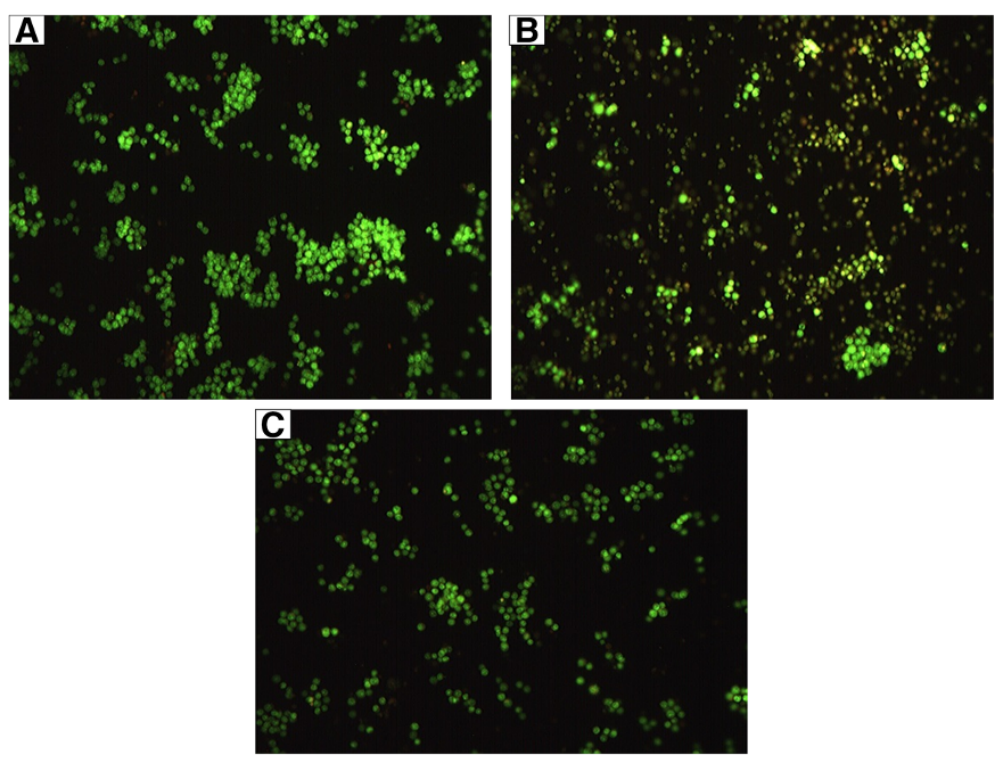

Figure 2 Acridine orange (AO)-propidium iodide (PI) double staining cell morphological assessment. Morphological changes in SH-SY5Y cells pretreated with Oryzanol-rich fraction (ORF) for $24 \mathrm{~h}$ followed by subsequent exposure to $250 \mathrm{\mu M} \mathrm{H}_{2} \mathrm{O}_{2}$ for $24 \mathrm{~h}$. (A) untreated cells (control); (B) $250 \mu \mathrm{M} \mathrm{H} \mathrm{O}_{2}$ alone; (C) $100 \mu \mathrm{g} / \mathrm{mL}$ ORF $+250 \mu \mathrm{M} \mathrm{H}_{2} \mathrm{O}_{2}$. Viable cells are stained green by acridine orange; Late apoptotic and necrotic cells are stained orange and red by propidium iodide.

apoptosis/early necrosis and late necrosis states in comparison to untreated cells. The untreated cells showed $94 \% \pm 3.67 \%$ viability, while incubation with $250 \mu \mathrm{M}$ $\mathrm{H}_{2} \mathrm{O}_{2}$ reduced the cell viability, to only $16 \% \pm 3.97 \%$ represented by early apoptosis $(2 \% \pm 0.05 \%)$, late apoptosis $(39 \% \pm 2.2 \%)$ and necrosis $(43 \% \pm 3.85 \%)$. The results indicated that $\mathrm{H}_{2} \mathrm{O}_{2}$ at $250 \mu \mathrm{M}$ was highly toxic to SHSY5Y cells. Pretreatment with ORF $(100 \mu \mathrm{g} / \mathrm{mL})$, however, protected the cells against $\mathrm{H}_{2} \mathrm{O}_{2}$-induced apoptosis, as demonstrated by $92.41 \% \pm 3.3 \%$ viability, which was similar to the untreated cells (Figure 4).

Effects of ORF on transcriptomic regulation of apoptotic and antioxidant genes in SH-SY5Y cells exposed to $\mathrm{H}_{2} \mathrm{O}_{2}$ $\mathrm{H}_{2} \mathrm{O}_{2}$-treatment induced upregulation of antioxidant genes in SH-SY5Y cells in comparison to untreated cells

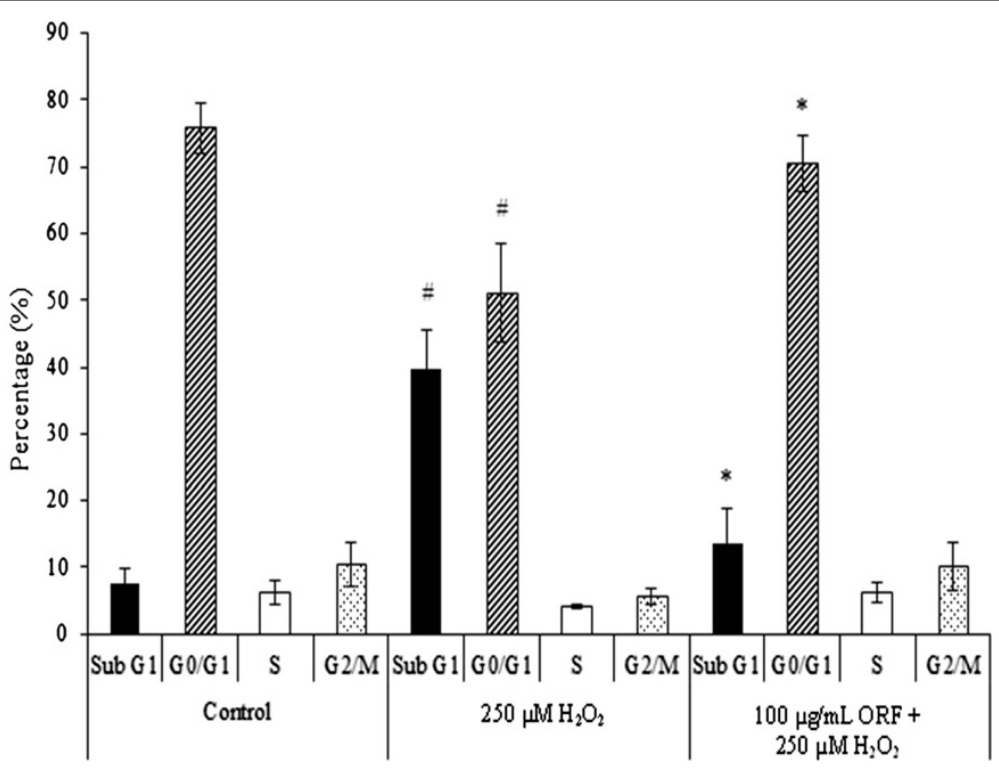

Figure 3 Cell cycle analysis. Flow cytometric measurement of cell death and cell cycle on SH-SY5Y cells pretreated with Oryzanol-rich fraction (ORF) $(100 \mu \mathrm{g} / \mathrm{mL})$ before exposure to $250 \mu \mathrm{M} \mathrm{H}_{2} \mathrm{O}_{2}$ over $24 \mathrm{~h}$. Results are mean $\pm \mathrm{SD} .{ }^{*} p<0.05$ versus control, ${ }^{*} p<0.05$ versus $\mathrm{H}_{2} \mathrm{O}_{2}$. 


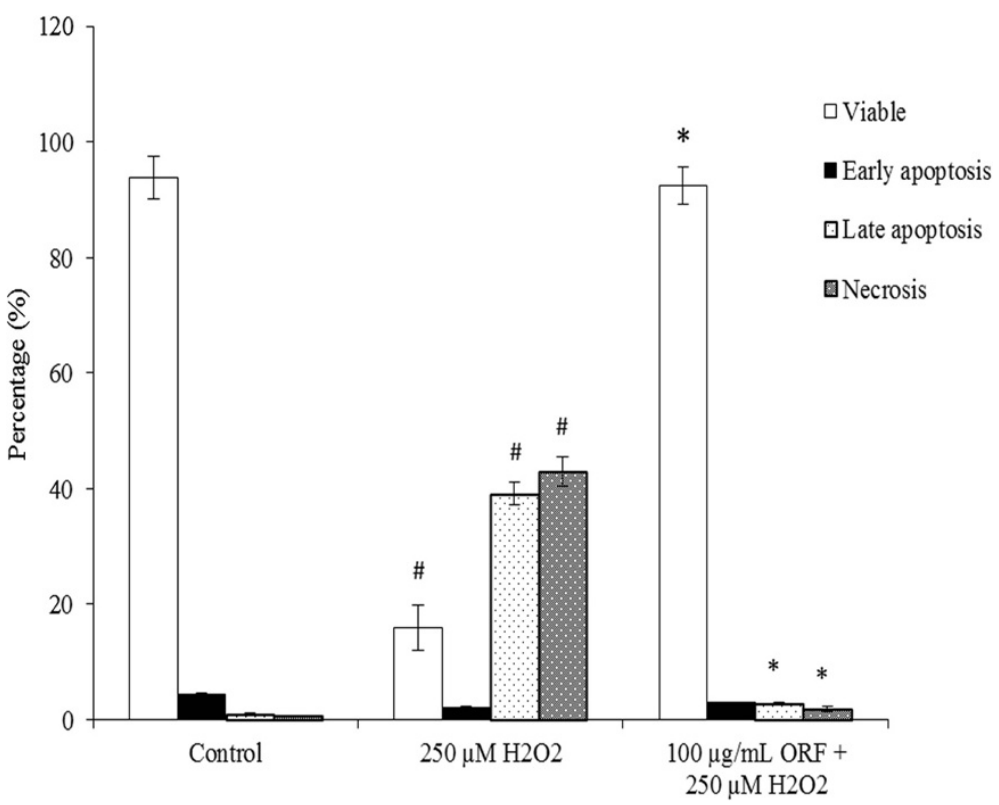

Figure 4 Annexin V-FITC and propidium iodide staining assay of SH-SY5Y cells following exposure to $250 \mu \mathrm{M} \mathrm{H}_{2} \mathrm{O}_{2}$ over $24 \mathrm{~h}$, in the presence or absence of $24 \mathrm{~h}$ Oryzanol-rich fraction (ORF) $(100 \mu \mathrm{g} / \mathrm{mL})$ pretreatment. Results are mean $\pm \mathrm{SD}$. ${ }^{\#} p<0.05$ versus control, * $p<0.05$ versus $\mathrm{H}_{2} \mathrm{O}_{2}$

(Figure 5A). Furthermore, pretreatment of SH-SY5Y cells with ORF $(100 \mu \mathrm{g} / \mathrm{mL})$ prior to $\mathrm{H}_{2} \mathrm{O}_{2}$ exposure upregulated catalase, SOD 1 and SOD 2 genes more than with $\mathrm{H}_{2} \mathrm{O}_{2}$ exposure alone or in untreated cells $(p<0.05)$. Additionally, $\mathrm{H}_{2} \mathrm{O}_{2}$ significantly upregulated $(p<0.05)$ the expression levels of TNF, ING3, BAK1, BAX, p21, caspase-9 and BcL-2 genes, but not BAD gene, in comparison to untreated cells (Figure 5B). Pretreatment with ORF $(100 \mu \mathrm{g} / \mathrm{mL})$ resulted in downregulation of the expression levels of TNF, ING3, BAK1, BAX, p21 and caspase-9 genes, $(p<0.05)$. In the presence of $\mathrm{H}_{2} \mathrm{O}_{2}, \mathrm{SH}-\mathrm{SY} 5 \mathrm{Y}$ cells showed significantly upregulated $(p<0.05)$ JNK and NF-K $\beta$ gene expression levels, and downregulated ERK1/2, AKT1 and p38 levels, in comparison to untreated cells. No changes were observed for p53 and PARP1 expression levels (Figure 5C). Pretreatment with ORF $(100 \mu \mathrm{g} / \mathrm{mL})$ upregulated the expression of ERK1/2, PARP1, AKT1 and NF-K $\beta$ genes, $(p<0.05)$, but downregulated that of JNK.

\section{Discussion}

In the present study, the neuroprotective effects of ORF were evaluated against toxicity caused by $\mathrm{H}_{2} \mathrm{O}_{2}$ on differentiated SH-SY5Y cells. Also, to minimize hazards associated with extraction of plant bioresources, a green technology (SFE) was used to extract ORF. In neuronal cells, $\mathrm{H}_{2} \mathrm{O}_{2}$ activates intracellular defence mechanisms including the upregulation of endogenous antioxidants, which are meant to protect cells from damage by $\mathrm{H}_{2} \mathrm{O}_{2}$. However, in excess, apoptosis and cell death ensue when the defence mechanisms fail to counter the effects of the
$\mathrm{H}_{2} \mathrm{O}_{2}$ [25]. The increasing interest in plant bioresources that can potentiate antioxidant systems is based on the notion that beyond the normal cellular threshold for apoptosis and cell death, such exogenous antioxidants could complement the cellular defence systems in countering $\mathrm{H}_{2} \mathrm{O}_{2}$-induced damage $[1,26,27]$. In this study, cell viability and morphology of $\mathrm{SH}-\mathrm{SY} 5 \mathrm{Y}$ cells were preserved by ORF in the presence of $\mathrm{H}_{2} \mathrm{O}_{2}$, suggesting that ORF likely was able to alter some pathways leading upto oxidative damage and/or apoptosis. The protective effects of ORF against $\mathrm{H}_{2} \mathrm{O}_{2}$-induced cell death were further corroborated by flow cytometric analyses, which indicated that ORF reduced the apoptotic and necrotic cells' population in SH-SY5Y cells.

Changes in the expression of antioxidant genes in the present study due to $\mathrm{H}_{2} \mathrm{O}_{2}$ are similar to what we have reported previously [28]. These changes suggested activation of antioxidant defence systems in SH-SY5Y cells to counter $\mathrm{H}_{2} \mathrm{O}_{2}$. The presence of ORF potentiated the expression of the antioxidant genes, suggesting further protection for the cells. As can be recalled, a very close link exists between pathways leading up to cell survival and those that mediate apoptosis and cell death due to oxidative damage. MAPKs and Akt are believed to be involved in these processes including cell growth, survival, differentiation and apoptosis responses [29]. Oxidative stress is reported to induce apoptotic cell death through activation of transcriptional factors such as MAPKs [25], and especially JNK [30,31], which is known to be involved in pro-apoptotic signaling [32]. JNK activation facilitates 


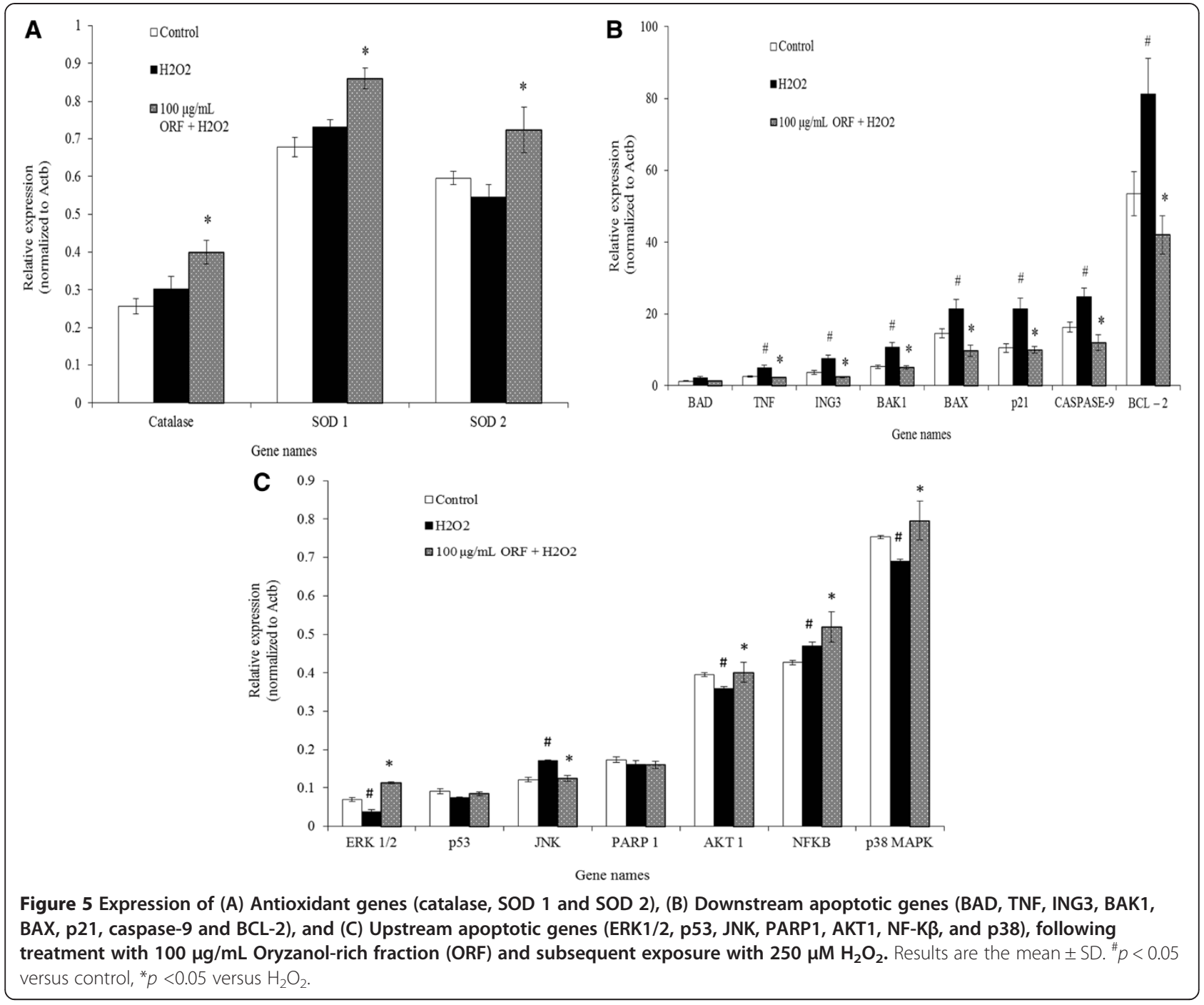

the decrease of mitochondrial membrane potential followed by release of cytochrome c, which then activates caspase- 9 and caspase- 3 , eventually leading to cell death [33]. Our results showed that $\mathrm{H}_{2} \mathrm{O}_{2}$ induced JNK and caspase- 9 activation, which were both attenuated by ORF treatment, suggesting that the protective effects of ORF against $\mathrm{H}_{2} \mathrm{O}_{2}$-induced injury in SH-SY5Y cells were partly mediated through its protection of the mitochondria.

Activation of ERK due to oxidative stress is reportedly mediated by growth factor receptors [34-36]. When growth factor receptors undergo phosphorylation in response to oxidative insults such as $\mathrm{H}_{2} \mathrm{O}_{2}$, the resulting changes attenuate ERK activation. Similarly, expression of inactive mutant forms of various growth factor receptors reduces activation of ERK by oxidative stress [34], while over expression of certain normal growth factor receptors in rat PC12 cells exposed to $\mathrm{H}_{2} \mathrm{O}_{2}$, results in enhanced activation of ERK [37]. Observations like these have given rise to suggestions of ERK activation as a survival factor following oxidative injury $[38,39]$. In the present study, $\mathrm{H}_{2} \mathrm{O}_{2}$ downregulated ERK1/2 gene expression, while ORF pretreatment resulted in upregulation of the gene. This suggested that in response to $\mathrm{H}_{2} \mathrm{O}_{2}$-induced oxidative stress, ORF pretreatment may trigger the expression of growth factor receptors in SH-SY5Y cells leading to activation of ERK1/2 gene as a protective mechanism. In addition, p38 MAPK is known to be a stress kinase, and its activation may lead to cell death. However, while this assumption is correct in most cases, cause-effect studies have also found that activation of p38 MAPK by stress stimuli may not necessarily promote death, but sometimes could enhances cell survival and DNA repair [40]. Similarly, activation of Akt in response to oxidant exposure appears to be mediated through growth factor receptors also [41]. In SH-SY5Y cells, Akt activation is linked to inhibition of apoptosis especially in the presence of oxidative stress $[42,43]$. In the present study, upregulation of Akt by ORF pretreatment suggested that ORF was anti-apoptotic. 
Dysregulation of TNF production has been implicated in a variety of human diseases. Binding of TNF to its receptor may result in activation of $N F-\kappa B$, activation of MAPK pathways or induction of death signaling. NF- $\mathrm{kB}$ is a heterodimeric transcription factor and translocates to the nucleus to mediate the transcription of a vast array of proteins involved in cell survival and proliferation, inflammatory response and anti-apoptotic factors. ORF pretreatment enhanced the gene expression of NF- $\mathrm{kB}$, indicating that NF-kB signaling pathway was likely involved in promoting survival and anti-apoptosis in SH-SY5Y in the presence of oxidative damage.

Oxidative stress often leads to cell death through apoptosis, and in the present study, activation of the genes encoding the Bcl-2 family proteins (i.e. Bcl-2, Bak1 and Bax) and caspase- 9 suggested the activation of apoptosis in the cells. Caspase- 9 is thought to activate caspase-3, which is known to cleave many nuclear DNA repair enzymes, such as PARP, resulting in nuclear DNA damage and apoptosis [3]. Moreover, ING3 overexpression was also reported to have induced apoptosis in RKO cells, through activation of p21 and Bax [44]. Upregulation of ING3 in the present study due to $\mathrm{H}_{2} \mathrm{O}_{2}$, therefore, also suggested induction of apoptosis in the cells. Interestingly, ORF pretreatment resulted in downregulation of Bcl-2, Bak1, Bax, p21, ING3 and caspase-9, indicating a tendency for anti-apoptosis.

Taken together, ORF was found to protect SH-SY5Y cells against $\mathrm{H}_{2} \mathrm{O}_{2}$-induced neurotoxicity possibly through multi-signaling pathways (Figure 6). The protective effects of ORF on SH-SY5Y cells were likely mediated through upregulation of antioxidant genes (catalase, SOD 1 and SOD 2), downregulation of pro-apoptotic genes (JNK, TNF, ING3, BAK1, BAX, p21 and caspase-9), and upregulation of anti-apoptotic genes (ERK1/2, AKT1 and NF-K $\beta$ ). The findings from this study suggest that rice bran could potentially be a source of antioxidants that

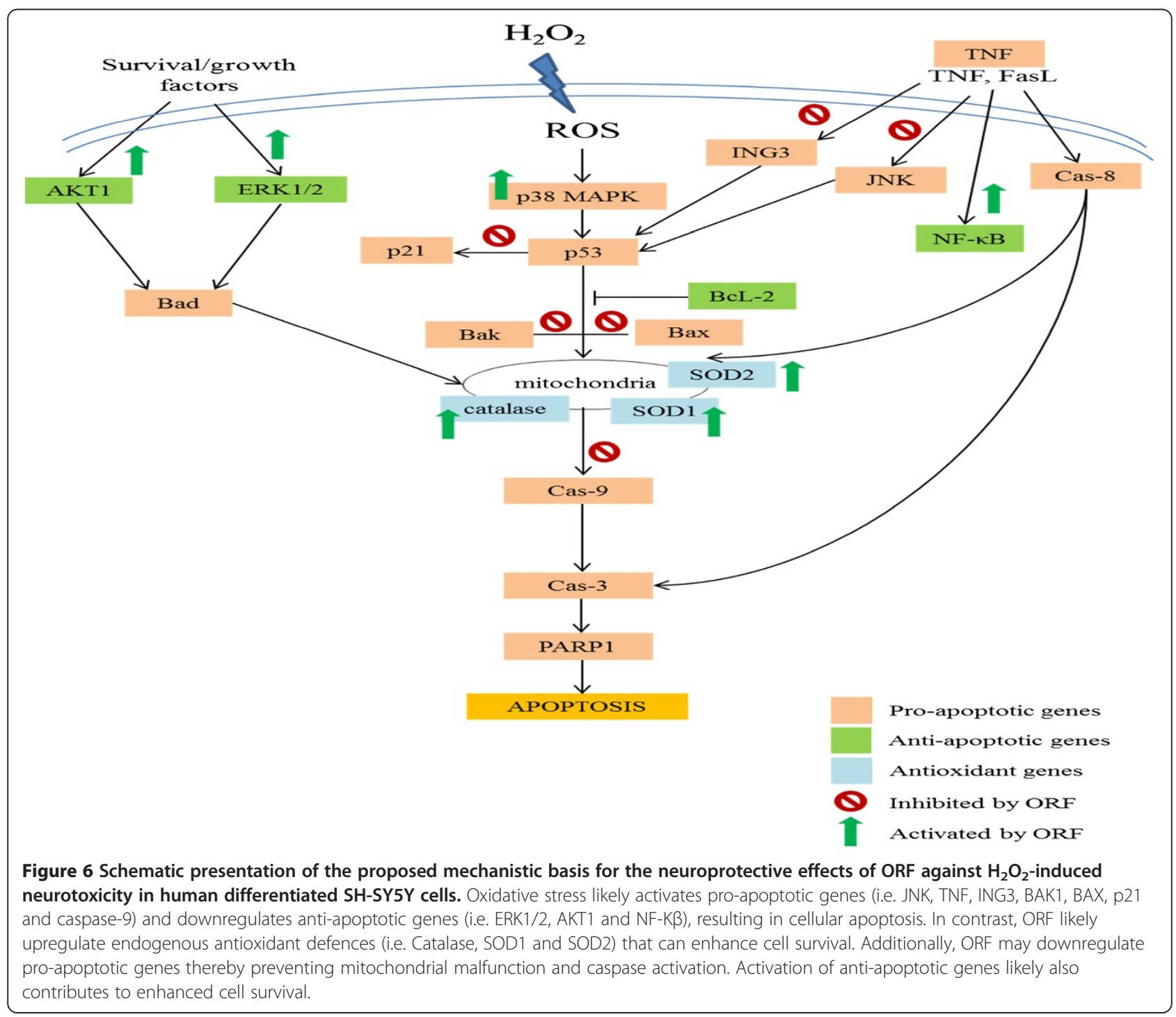


may have huge implications on the study and management of neurodegerative diseases.

\section{Conclusions}

In this study, ORF protected $\mathrm{SH}-\mathrm{SY} 5 \mathrm{Y}$ cells against $\mathrm{H}_{2} \mathrm{O}_{2}$ induced neurotoxicity as evidenced by the reduced cytotoxicity, inhibition of apoptosis, and gene expression changes (upregulation of antioxidant genes, downregulation of pro-apoptotic genes, and upregulation of antiapoptotic genes) that tended towards cell survival. The results suggested that ORF could protect SH-SY5Y cells against oxidative stress-mediated apoptosis. These findings could have huge implications on future studies on the potential use of ORF in managing neurodegenerative diseases caused by oxidative injury.

\section{Abbreviations}

AKT- v: Akt murine thymoma viral oncogene; AO-PI: Acridine orangepropidium iodide; BAD: BCl-2-associated death promoter; BAK1: BCL2-antagonist/killer 1; BAX: BCl-2-associated X; ERK: Extracellular regulated kinase; $\mathrm{H}_{2} \mathrm{O}_{2}$ : Hydrogen peroxide; ING3: Inhibitor of growth 3; JNK- C: Jun N-terminal kinase; MAPK: Mitogen-activated protein kinases; MTT: (3-[4,5-dimethylthiazol-2-yl]-2,5-diphenyl-tetrazolium bromide); NF-KB: Nuclear factor kappa B; ORF: Oryzanol-rich fraction; P13K: Phosphoinositide 3-kinase; p21: Tumor suppressor gene 21; ROS: Reactive oxygen species; SFE: Supercritical carbon dioxide fluid extraction; SOD: Superoxide dismutase; TNF: Tumor necrosis factor

\section{Competing interests}

The authors declare that they have no competing interests.

\section{Authors' contributions}

$\mathrm{NI}$ and $\mathrm{MI}$ designed the study. NI, MUI, NHA, SFF and JBF performed the experiments. $\mathrm{NI}$ and $\mathrm{MUI}$ drafted the manuscript, while $\mathrm{MI}$ reviewed the manuscript before final submission. MFAB prepared stabilised rice bran and oRF for the study. All authors read and approved the final manuscript.

\section{Acknowledgements}

This study was funded in part by Padiberas National Berhad (BERNAS, Malaysia) and the Grants from the Research University Grant Scheme, Universiti Putra Malaysia (vote no. 91620).

Received: 22 April 2014 Accepted: 21 November 2014

Published: 5 December 2014

\section{References}

1. Martindale $\mathrm{L}$, Holbrook NJ: Cellular response to oxidative stress: signaling for suicide and survival. J Cell Physiol 2002, 192(1):1-15.

2. Melo A, Monteiro L, Lima RMF, De Oliveira DM, De Cerqueira MD, El-Bachá RS: Oxidative stress in neurodegenerative diseases: mechanisms and therapeutic perspectives. Oxid Med Cell Longev 2011, 2011:467180.

3. Sugawara T, Fujimura M, Noshita N, Kim GW, Saito A, Hayashi T, Narasimhan $\mathrm{P}$, Maier CM, Chan PH: Neuronal death/survival signaling pathways in cerebral ischemia. Neuro RX 2004, 1(1):17-25.

4. Mattson MP, Camandola S: NF-KB in neuronal plasticity and neurodegenerative disorders. J Clin Invest 2001, 107(3):247-254.

5. Laokuldilok T, Shoemaker CF, Jongkaewwattana S, Tulyathan V: Antioxidants and antioxidant activity of several pigmented rice brans. J Agric Food Chem 2011, 59:193-199.

6. Jariwalla RJ: Rice-bran products: phytonutrients with potential applications in preventive and clinical medicine. Drugs ExpClin Res 2001, 27:17-26.

7. Ha TY, Han S, Kim SR, Kim IH, Lee HY, Kim HK: Bioactive components in rice bran oil improve lipid profiles in rats fed a high-cholesterol diet. Nutr Res 2005, 25:597-606.
8. Jeng TL, Ho PT, Shih YJ, Lai CC, Wu MT, Sung JM: Comparisons of protein, lipid, phenolics, $\mathrm{Y}$-oryzanol, vitamin $\mathrm{E}$, and mineral contents in bran layer of sodium azide-induced red rice mutants. J Sci Food Agric 2011, 91:1459-1465.

9. Fabian $\mathrm{C}$, Ju $\mathrm{YH}$ : A review on rice bran protein: its properties and extraction methods. Crit Rev Food Sci Nutr 2011, 51:816-827.

10. Ermak S, Dunford NT: Policosanol contents and composition of wheat varieties. J Agric Food Chem 2005, 53:5583-5586.

11. Wang T, Hicks KB, Moreau R: Antioxidant activity of phytosterols, oryzanol, and other phytosterols conjugates. J Am Oil Chem Soc 2002, 79:1201-1206.

12. Srinivasan M, Sudheer AR, Menon VP: Ferulic acid: therapeutic potential through its antioxidant property. J Clin Biochem Nutr 2007, 40:92-100.

13. Hudson EA, Dinh PA, Kokubun T, Simmonds MS, Gescher A: Characterization of potentially chemopreventive phenols in extracts of brown rice that inhibit the growth of human breast and colon cancer cells. Cancer Epidemiol Biomarkers Prev 2000, 9(11):1163-1170.

14. Ardiansyah SH, Koseki T, Hashizume K, Komai M: The Driselase-treated fraction of rice bran is a more effective dietary factor to improve hypertension, glucose and lipid metabolism in stroke-prone spontaneously hypertensive rats compared to ferulic acid. Br J Nutr 2007, 97:67-76.

15. Kaup RM, Khayyal MT, Verspohl EJ: Antidiabetic effects of standardized Egyptian rice bran extract. Phytother Res 2013, 27(2):264-271

16. Al-Naqeep G, Ismail M, Allaudin Z: Regulation of low-density lipoprotein receptor and 3-hydroxy-3-methylglutaryl coenzyme A reductase gene expression by thymoquinone-rich fraction and thymoquinone in HepG2 cells. J Nutrigenet Nutrigenomics 2009, 2:163-172.

17. Chan KW, Ismail M: Supercritical carbon dioxide fluid extraction of Hibiscus cannabinus L. seed oil: a potential solvent-free and high antioxidative edible oil. Food Chem 2009, 114:970-975.

18. Ismail M, Al-Naqeeb G, Mamat WA, Ahmad Z: Gamma-oryzanol rich fraction regulates the expression of antioxidant and oxidative stress related genes in stressed rat's liver. Nutr Met 2010, 7(23):1-13.

19. Ismail M, Al-Naqeep G, Chan KW: Nigella sativa thymoquinone-rich fraction greatly improves plasma antioxidant capacity and expression of antioxidant genes in hypercholesterolemic rats. Free Radic Biol Med 2010, 48:664-672

20. Norsharina I, Maznah I, Aied A, Al-Naqeeb G: Thymoquinone rich fraction from Nigella sativa and thymoquinone are cytotoxic towards colon and leukemic carcinoma cell lines. J Med Plants Res 2011, 5(15):3359-3366.

21. Mariod AA, Mattha" us B, Ismail M: Comparison of supercritical fluid and hexane extraction methods in extracting Kenaf (Hibiscus cannabinus) seed oil lipids. J Am Oil Chem Soc 2011, 88:931-935.

22. Foo JB, Yazan LS, Mansor SM, Ismail N, Tahir PM, Ismail M: Kenaf seed oil from supercritical carbon dioxide fluid extraction inhibits the proliferation of WEHI-3B leukemia cells in vivo. J Med Plants Res 2012, 6(8):1429-1436.

23. Ghafar SAA, Ismail M, Yazan LS, Fakurazi S, Ismail N, Chan KW, Tahir PM: Cytotoxic activity of Kenaf seed oils from supercritical carbon dioxide fluid extraction towards human colorectal cancer (HT29) cell lines. Evid Based Complement Alternat Med 2013, 2013:549705.

24. Ismail N, Ismail M, Fathy SF, Musa SNA, Imam MU, Foo JB, Iqbal S: Neuroprotective effects of germinated brown rice against hydrogen peroxide induced cell death in human SH-SY5Y cells. Int J Mol Sci 2012, 13:9692-9708

25. Klein JA, Ackerman SL: Oxidative stress, cell cycle, and neurodegeneration. J Clin Invest 2003, 111(6):785-793.

26. Gandhi S, Abramov AY: Mechanism of oxidative stress in neurodegeneration. Oxid Med Cell Longev 2012, 2012:428010.

27. Pocernich CB, Lange ML, Sultana R, Butterfield DA: Nutritional approaches to modulate oxidative stress in Alzheimer's disease. Curr Alzheimer Res 2011, 8(5):452-469.

28. Azmi NH, Ismail N, Imam MU, Ismail M: Ethyl acetate extract of germinated brown rice attenuates hydrogen peroxide-induced oxidative stress in human SH-SY5Y neuroblastoma cells: role of anti-apoptotic, pro-survival and antioxidant genes. BMC Complement Alternat Med 2013, 13:177.

29. Liu CL, Xie LX, Li M, Durairajan SSK, Goto S, Huang JD: Salvianolic acid B inhibits hydrogen peroxide-induced endothelial cell apoptosis through regulating PI3K/Akt signalling. PLOS One 2007, 12:e1321.

30. Pugazhenthi S, Wang M, Pham S, Sze Cl, Eckman CB: Downregulation of CREB expression in Alzheimer's brain and in $A \beta$-treated rat hippocampal neurons. Mol Neurodegener 2011, 6:60. 
31. Yi-Rong C, Anju S, Tse-Hua T: Down-regulation of the c-Jun N-terminal kinase (JNK) phosphatase M3/6 and activation of JNK by hydrogen peroxide and pyrrolidinedithiocarbamate. Oncogene Res 2001, 20:367-374.

32. Kutuk $\mathrm{O}$, Basaga $\mathrm{H}$ : Apoptosis signalling by 4-hydroxynonenal: a role for JNK-c-Jun/AP-1 pathway. Redox Rep 2007, 12(1):30-34

33. Luo J, Robinson JP, Shi R: Acrolein-induced cell death in PC12 cells: role of mitochondria-mediated oxidative stress. Neurochem Int 2005 47:449-457.

34. Sachsenmaier C, Radler-Pohl A, Zinck R, Nordheim A, Herrlich P, Rahmsdorf HJ: Involvement of growth factor receptors in the mammalian UVC response. Cell 1994, 78:963-972.

35. Schieven GL, Mittler RS, Nadler SG, Kirihara JM, Bolen JB, Kanner SB, Ledbetter JA: ZAP-70 tyrosine kinase, CD45, and T cell receptor involvement in UV- and $\mathrm{H} 2 \mathrm{O} 2$-induced T cell signal transduction. J Biol Chem 1994, 269:20718-20726.

36. Huang RP, Wu JX, Fan Y, Adamson ED: UV activates growth factor receptors via reactive oxygen intermediates. J Cell Biol 1996, 133:211-220.

37. Guyton KZ, Gorospe M, Wang X, Mock YD, Kokkonen GC, Liu Y, Roth GS, Holbrook NJ: Age-related changes in activation of mitogen-activated protein kinase cascades by oxidative stress. I Investig Dermatol Symp Proc 1998, 3:23-27.

38. Guyton KZ, Gorospe M, Kensler TW, Holbrook NJ: Mitogen activated protein kinase (MAPK) activation by butylatedhydroxytoluenehydroperoxide: implications for cellular survival and tumor promotion. Cancer Res 1996, 56:3480-3485.

39. Guyton KZ, Liu Y, Gorospe M, Xu Q, Holbrook NJ: Activation of mitogenactivated protein kinase by $\mathrm{H}_{2} \mathrm{O}_{2}$. Role in cell survival following oxidant injury. J Biol Chem 1996, 271:4138-4142.

40. Thornton TM, Rincon M: Non-classical p38 Map Kinase functions: cell cycle checkpoints and survival. Int J Bio/Sci 2009, 5(1):44-52.

41. Wang X, McCullough KD, Franke TF, Holbrook NJ: Epidermal growth factor receptor-dependent Akt activation by oxidative stress enhances cell survival. J Biol Chem 2000, 275:14624-14631.

42. Canas N, Valero T, Villarroya M, Montell E, Vergés J, García AG, López MG: Chondroitin sulfate protects SH-SY5Y cells from oxidative stress by inducing heme oxygenase-1 via phosphatidylinositol 3-kinase/Akt. J Pharmacol Exp Ther 2007, 323:946-953.

43. Heo SR, Han AM, Kwon YK, Joung I: p62 protects SH-SY5Y neuroblastoma cells against $\mathrm{H}_{2} \mathrm{O}_{2}$-induced injury through the PDK1/Akt pathway. Neurosci Lett 2009, 450:45-50

44. Nagashima M, Shiseki M, Pedeux RM, Okamura S, Kitahama-Shiseki M, Miura K, Yokota J, Harris CC: A novel PHD-finger motif protein, p47ING3, modulates p53-mediated transcription, cell cycle control, and apoptosis. Oncogene 2003, 22:343-350.

doi:10.1186/1472-6882-14-467

Cite this article as: Ismail et al:: Mechanistic basis for protection of differentiated SH-SY5Y cells by oryzanol-rich fraction against hydrogen peroxide-induced neurotoxicity. BMC Complementary and Alternative Medicine 2014 14:467.

\section{Submit your next manuscript to BioMed Central and take full advantage of:}

- Convenient online submission

- Thorough peer review

- No space constraints or color figure charges

- Immediate publication on acceptance

- Inclusion in PubMed, CAS, Scopus and Google Scholar

- Research which is freely available for redistribution 